\title{
How Our Life Experiences Affect Our Politics: The Roles of Vested Interest and Affect in Shaping Policy Preferences
}

\author{
Gregory A. Petrow and Timothy Vercellotti
}

Scholars investigating the role of self-interest in determining policy preferences find that selfinterest has weak effects. However, researchers have refined their concepts of self-interest and are now finding a greater role for it (e.g., Crano 1995). We continue along this line of research, considering different mechanisms by which self-interest may come to be important. We argue that measuring people's perceived self-interest in a policy (which we call vested interest) is important for understanding how people pursue their self-interest. We find that while life circumstances can cause people to endorse vested interest, emotion is an important mediator of this relationship. Finally, we test the notion that value change mediates between vested interest and support for a policy, and find evidence for a reciprocal relationship.

If asked in casual conversation, most scholars knowledgeable about political behavior would downplay the connection between individuals' life events and their politics. In all likelihood, however, that conclusion would probably be met with skepticism by the other conversation participants. Indeed, the simple and intuitive relationship between people's experiences, self interest, and their politics forms the bedrock of democratic theory (e.g., Hamilton et al. 1961). Much of the relevant literature, however, concludes there is no relationship between self-interest and policy preferences. Instead, scholars usually find that symbolic attitudes, such as political ideology, have the most consistent and powerful effects (see Sears and Funk 1991 for a review). ${ }^{1}$

There is a developing literature, however, that is exploring the link between self-interest and policy attitudes (e.g., Crano 1995). This paper advances that literature and takes a step toward explaining how the events that befall people affect their political attitudes. While the effects of these events on policy preferences might operate through a variety of mechanisms, we argue that people's perceived self-interest (which we and other scholars label "vested interest") is an important factor to consider. In other words, we propose a model of how events in people's lives cause them to believe that certain public policies are in their self-interest, thus increasing support for

Data upon which this research is based are from the Elon University Poll, Elon University Institute of Politics and Public Affairs, Elon, NC, April 2005.

GREGORY A. PETROW is assistant professor of political science at University of Nebraska at Omaha. TIMOTHY VERCELLOTTI is associate professor of political science at Western New England College.

The American Review of Politics, Vol. 32, Spring, 2011: 3-29

(C)2011 The American Review of Politics 
those policies. We call those life-changing events the antecedents of selfinterest.

We refer to two literatures in building our theory. First, we consider the symbolic politics literature. Scholars in this literature demonstrate the powerful and consistent relationship between people's symbolic predispositions and policy preferences, while at the same time emphasizing the weak relationship between people's life circumstances (as manifested by their selfinterest) and their policy preferences. ${ }^{2}$ Second, the vested interest literature attempts to buttress the modest role allowed for life events by explaining that when people perceive that certain public policies are in their selfinterest, they support those policies (e.g., Crano 1995). The crucial difference between the two literatures is in conceptualizing, and then measuring, self-interest.

In the symbolic politics research, scholars assume that certain circumstances ought to routinely produce self-interest. For example, someone lacking health insurance should support a national health care program, or someone whose child is bused across town should oppose school busing to desegregate schools. In the vested interest literature, however, self-interest is seen as a psychological process that varies between individuals. The vested interest literature explores how antecedents of self-interest lead some people to perceive that certain policies are in their self-interest, thus increasing support for the policy. ${ }^{3}$

In addition, we introduce a provocative hypothesis-that when people believe they will benefit from a certain policy, that belief causes individuals to change their political values in a way that is consistent with support for the policy. We further expect that emotion will mediate the relationships between the antecedents of self-interest and their vested interest, as well as the antecedents of self-interest and policy preferences.

In this paper we develop a model that incorporates the antecedents of self-interest, vested interest, political values, and emotion as predictors of preferences for public policy. We test the model using a specific policy-a government-backed national health insurance program. We chose national health insurance because health care costs constitute a growing proportion of household expenditures, and the percentage of the adult, non-elderly population in the United States that lacks health insurance has risen steadily in recent years (Holahan and Cook 2005).

This paper seeks to advance the literature in three important ways. First, we consider the mechanism by which people's changing life circumstances - which we term antecedents of self-interest-might affect a policy preference. We, like others, expect them to affect vested interest (e.g., Boninger et al. 1995). In turn, we expect that the effect of vested interest can be mediated by a change in an important symbolic predisposition-the 
political value that is associated in citizens' minds with the public policy. If we find evidence for this relationship, it will be a radical change in scholars' understanding of how political values operate in influencing policy preferences.

Second, we take these models out of the domain of the purely cognitive to consider affect. We predict that life events that evoke self-interest and group interest also will generate emotions that influence vested interest and policy preferences.

Third, we test the causal direction of two key sets of variables - vested interest and political values. Scholars to date have rejected the possibility that political values, which are considered long-enduring predispositions, can be affected by self-interest (Sears and Funk 1991), but we argue here for a chance to test this assumption. We accept that symbolic and abstract beliefs serve as stable guiding principles, but we seek to tell a more complete story that involves conditions under which people may adjust their beliefs in response to life circumstances.

\section{Theory and Hypotheses}

The theoretical model is displayed in Figure 1. We view the antecedents of self-interest as the beginning of the causal chain in the model. The point of the study is to understand how people's changing life circumstances prompt them to perceive that certain public policies are in their selfinterest, thus causing them to hold a vested interest. These situations stimulate affect, which we predict mediates between the antecedents of selfinterest and vested interest. Taken broadly, different types of antecedents of self-interest will stimulate different emotions.

We believe that situations that lead to someone not being able to pay his or her medical bills will cause anxiety. This hypothesis is consistent with the work of Ortony et al. (1988), who considered anxiety to be a "fear emotion" that results when one is displeased about the prospect of an undesirable event. Certainly, not being able to pay medical bills would lead to deep dread, as one's health care can be denied, and many even have to file for bankruptcy after not being able to pay resulting debts. Thus we predict that:

Hypothesis 1: Antecedents of self-interest increase anxiety about paying for health care.

Broadly speaking, anxiety has several effects, mainly causing greater processing of information and learning. Political scientists find this effect in political campaigns (Marcus et al. 2000; MacKuen et al. 2007), when people search the Internet during political campaigns (Valentino et al. 2008; 
Figure 1. Theoretical Model of Vested Interest and Policy Support

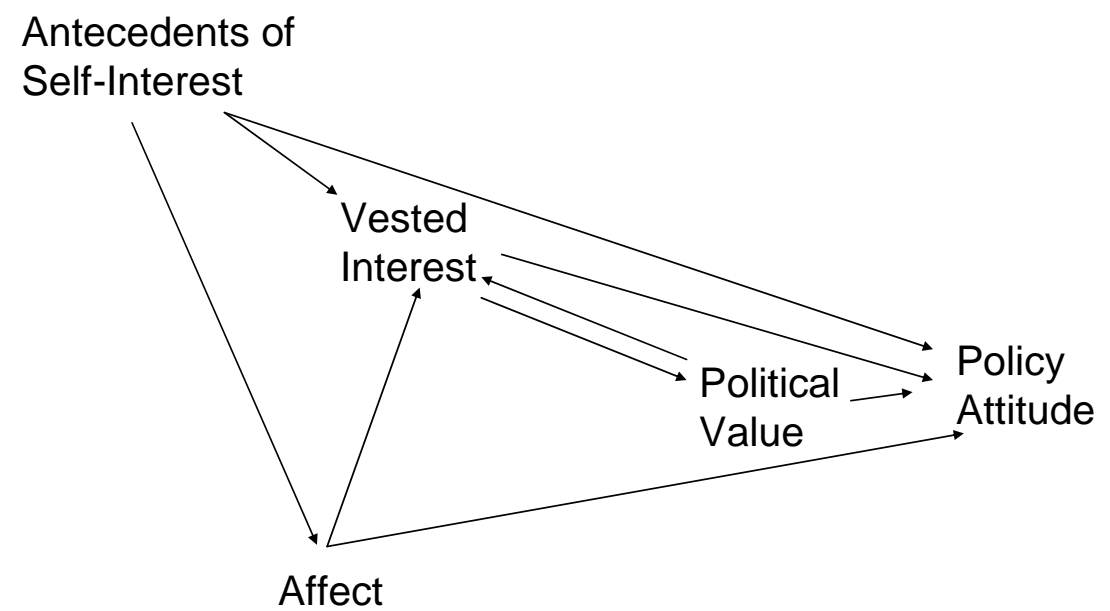

Valentino et al. 2009), and to a limited extent during the run-up to the War in Iraq (Huddy et al. 2007). However, the role of anxiety is clearly, to some extent, contextual. People anxious about a presidential candidate are more interested in the campaign, but only those people high in internal efficacy (Rudolph et al. 2000). Anxiety may only promote learning if people believe they can overcome the threats they face (Nadeau et al. 1995). Too much anxiety can limit processing, and learning, because people engage in avoidance behaviors (LeDoux 1996; Panskepp 1998). After people have chosen a candidate in an election, anxiety about that candidate only leads to more learning when people discover unsetting information about the person, and then the learning only occurs about that candidate (Redlawsk et al. 2007). In the aftermath of $9 / 11$, the anxious did not learn more about the situation compared to the non-anxious, nor did they in the run-up to the War in Iraq (Feldman and Huddy 2005; Huddy et al. 2007).

Despite these limitations to the role of anxiety, there is still clearly a general relationship between greater anxiety and more information processing. ${ }^{4}$ However, even more important for this project is the finding that increased information-seeking displaces the dominant role usually played by people's long-standing symbolic predispositions, such as partisanship or ideological identification (Marcus et al. 2000; MacKuen et al. 2007).

The consequence of the greater processing is that people become thoughtful regarding the threat they face. They come to focus on the threat. The result is that people will give thought to solutions to their problems, and 
in the process, they are more likely to see a national health care program as a political solution. This would be the result because some will come to see that the policy will benefit them. These cognitive effects lead us to predict that anxiety will cause people to perceive they have a vested interest in the public policy. This is a result of anxiety prompting individuals to pay closer attention to relevant information, which then informs their views, as well as softens their commitment to their predispositions. We expect that:

\section{Hypothesis 2: Anxiety increases vested interest concerning health care.}

\section{The Role of Political Values}

Turning to the theoretical model as displayed in Figure 1, the vested interest may then affect the political value by prompting individuals to align their value to be consistent with their vested interest. This is a position at odds with what we call the "consensus view" of political values. Scholars with this view argue that values are learned through an uncritical socialization process in childhood, and that values are guiding principles that shape subordinate attitudes, but not vice-versa (e.g., Sears and Funk 1999, Feldman and Steenbergen 2001). A core claim of the "consensus view" is that self-interest never affects values (Sears and Funk 1991; see also Eagly and Chaiken 1998).

However, an alternative view is that values often are truisms with little cognitive support. They are composed of affect and behavioral associations (that is, value-consistent behaviors). Thus, if life circumstances are sufficiently powerful, people may reexamine their limited cognitive support for values and thus change their values (Maio and Olson 1998; Bernard et al. 2003). Scholars have shown that values only affect choices and behaviors when they are cognitively activated and central to one's self-concept (Verplanken and Hollard 2002). McCann (1997) argues that values are not more stable than other attitudes. Furthermore, Boninger et al. (1995) find that selfinterest causes people to think of their political values, and Baron and Leshner (2000) find that protected values are amenable to change when challenged. Some of the most recent work on the malleability of political values finds that partisanship affects the political values people endorse, but not vice-versa (Goren 2005).

A consideration of the cognition of attitudes reveals how these values might, in fact, be changed when individuals consider their self-interest. One way that values and self-interest can become associated is if they are embedded attitudes in an associative network. Attitude embeddedness is the degree to which attitudes are associated with other attitudes (Prisline and 
Ouellette 1996). For those in the American electorate struggling with health care costs, we may expect that their values, self interest and support for national health insurance are embedded with one another because highly embedded attitudes are associated with the experience one has with an attitude object and with attitude-related knowledge (Prisline and Ouellette 1996). For those facing major medical bills, the personal benefit to them of national health insurance may become apparent. Because their political values are embedded in the same cognitive structures as policy preferences, they would align their relevant values (for which they have little cognitive support) to maintain cognitive consistency with their policy preference (Eagly and Chaiken 1998). ${ }^{5}$

We believe two core political values may be important for evaluating a national health insurance plan: that of active government, and egalitarianism. Active government is the degree to which people value a government that intervenes in the affairs of society (Markus 1990). In the context of access to health care, creating a national health insurance program would involve a dramatic expansion of the government's role. The value of egalitarianism is the degree to which one values equality of outcome, which involves eliminating societal inequalities with government intervention in the economic marketplace (e.g., Feldman 1987; Feldman and Steenbergen 2001). Creating a national health insurance program is a government action that would increase equality, and is likely to draw support from those also embrace egalitarianism.

Turning to the relationship between vested interest and values, we predict:

Hypothesis 3: Vested interest in the national health insurance condition increases the political values of active government and egalitarianism.

Furthermore, we expect that valuing active government and egalitarianism will cause support for a national health insurance program. This is because values and preferences are embedded in a hierarchical attitude structure whereby values cause policy preferences, and this holds for all types of people. It is inherent to human cognition that people use broad general principles to guide their decisions and actions. ${ }^{6}$ This leads to our understanding that in politics, people's preferences are generally consistent with their political values. And as we argue here, values are not frozen in place after adolescence, but change according to experience and new information. We expect that valuing active government, and equality in particular, should increase support for a national health insurance program because values are powerful determinants of peoples' policy preferences, and being 
predisposed toward government intervention and equality are congruent with programs that expand such government activism and promote equality (e.g., Feldman 1988). Hence, we predict:

Hypothesis 4: Active government and egalitarianism increase support for national health insurance.

Our final hypothesis is that vested interest increases support for a national health insurance program. Vested interest is said to exist when five criteria are satisfied: an actor perceives a stake in a given attitude object, the object is salient to the actor, the actor believes certain specific consequences ensue from an attitude-relevant action, the consequences are immediate, and the actor believes that his or her action can affect the attitude-implicated behavior (actor's self-efficacy; Crano 1995). In other words, vested interest requires that the attitude object be relevant to an individual's well-being and of perceived importance in terms of consequences (Lehman and Crano 2002). Such attitudes should be powerful for several reasons. Issues that are both personally relevant and that have perceived important consequences should prompt people to pay closer attention to the details of arguments regarding the issue. That heightened attention should result in greater thought about the topic and greater openness to being persuaded (Petty and Cacioppo 1986).

Hypothesis 5: Vested interest increases support for a national health insurance program.

\section{Data and Methodology}

We test our hypotheses using data from a random-digit-dial statewide telephone survey in North Carolina conducted April 18-26, 2005. The sample used in this research consists of interviews with 748 adults ages 18 and older. We weighted the data to reflect the distribution of the population of adults ages 18 and older in North Carolina based on gender, race, Hispanic/non-Hispanic, and age. Further details about the demographic composition of the sample, both weighted and unweighted, can be found in Appendix A.

The key endogenous variables for the model are:

Support for a national health care plan: "Would you support or oppose the creation of a government insurance plan that covers all medical and hospital costs for all citizens?" (5-point scale, with $1=$ strongly oppose it and 5 = strongly support it.) 
Political value of active government: An additive scale (alpha $=0.72$ ) combining responses to three questions about active government. (Full text of the questions is found in Appendix B.)

Political value of egalitarianism: Do you agree or disagree with the following statement: "All in all, I think economic differences in this country are justified.” (5-point scale, with $1=$ strongly agree and $5=$ strongly disagree.)

Vested interest: "Thinking about you personally and your life as it is, if the government set up a national health insurance plan, would the consequences for you, in general, be very positive, somewhat positive, somewhat negative, very negative, or would there be no consequences for you personally?" (5-point scale, with 1 = very negative and 5 = very positive.)

The model contains measures of the antecedents of self-interest, such as needing help paying medical bills; a prospective view of the health of the national economy in the coming year; and a measure of affect in the form of concern about being able to pay medical bills. The model also controls for political ideology, political party registration, gender, whether the respondent is African-American, education, annual household income, and the respondent's age. The model includes a squared age term to control for possible curvilinear effects of age. The very young and the elderly might be less supportive of national health care for different reasons. Young people tend to be healthier and in less need of medical care, and individuals ages 65 and older already are covered by Medicare.

We tested our hypotheses using Three-Stage Least Squares regression. Given the cross-sectional nature of the data, the only way to test for relationships between vested interest and political values is to allow each variable to affect the other. The resulting model is non-recursive, and using Ordinary Least Squares in the analysis is ill-advised. When we place the equations for vested interest and political values in reduced form, the independent variables in the equations are correlated with the error terms, leading to estimates that are biased and inconsistent (Berry 1984). The typical approach to analyzing non-recursive models is to use Two-Stage Least Squares, in which estimates for the reduced form equation are calculated in the first stage. The estimates for the dependent variables in question are then used to create instrumental predictors in the second stage that are not correlated with the error terms for the equations. Three-Stage Least Squares takes the model one step further by estimating all of the equations in the model simultaneously, which controls for the possibility that error terms for all or some of the equations in the model might be correlated with each other (Berry 1984; Godwin 1985). This is a more cautious approach to control for possible correlated error terms across the equations, and it presents two advantages. The models' estimates have smaller variances, making them more efficient than those in 
Two-Stage Least Squares (Godwin 1985). The model also produces a system-weighted R-squared statistic for the entire model. We can thus measure the explained variance for all of the endogenous variables in the model and compare the model fit between different nested models. TwoStage Least Squares generates R-squared statistics for the individual equations in the model, but those statistics are not meaningful for the nonrecursive equations given the feedback going on between the equations.

The disadvantage of using the Three-Stage Least Squares method is that it is a "full information" estimator, and thus carries with it the assumption that the model is properly specified. If specification errors seep into any of the model's equations, the error affects the estimations in all of the model's equations (Berry 1984; Godwin 1985). We believe our model is properly specified, based on our theory and previous findings from the literature. We also conducted diagnostic tests of the model to confirm that the model is well-specified, and that our identification and exclusion restriction assumptions are valid. We find this to be the case, and we report results in Appendix C.

We report our results using fully standardized coefficients, meaning the coefficients are in the metric of standard deviations. This allows us to compare the direct effects of vested interest and political values on each other despite the varying scales for the measures. Using fully standardized estimates also allows us to calculate direct and indirect effects for the models.

\section{Results}

\section{Reporting Apparent Effects}

We report the results for four models. The first two models are the fully-specified vested interest models, with measures of the antecedents of self-interest, vested interest, political values, and anxiety. The first model includes egalitarianism as the political value, and the second includes active government. The final two models are meant to represent the kinds of models political scientists traditionally estimate to ascertain the effects of "self-interest"- these include measures of the antecedents of self-interest to stand for self-interest, but excluding vested interest. We will contrast the two different stories these types of models tell. We present the results for Model 1 , including vested interest, and egalitarianism, in Table 1.

e find that all four of the antecedents of self-interest increase people's worry over being able to pay their health care bills $(\mathrm{p}<.01$ for all four results). The other factor that increases worry is age $(\mathrm{p}<.01)$, although age-squared and income both decrease worry $(\mathrm{p}<.01)$. The age-squared result indicates that advancing into the oldest ages decreases worry, probably 


\section{Table 1. The Vested Interest Model of Policy Support with Egalitarianism}

\begin{tabular}{|c|c|c|c|c|}
\hline Variables & Worry & $\begin{array}{l}\text { Vested } \\
\text { Interest }\end{array}$ & Egalitarianism & $\begin{array}{c}\text { National } \\
\text { Health Plan }\end{array}$ \\
\hline No health coverage & $.10^{* *}$ & .01 & & $.09 *$ \\
\hline Difficult to pay medical bills & $.29 * *$ & & & \\
\hline Delayed a major purchase & $.14^{* *}$ & & & \\
\hline Prospective personal finance & $.15^{* *}$ & & & \\
\hline Prospective national economy & .05 & & & \\
\hline Worry & & $.20^{*}$ & & $-.31 *$ \\
\hline Egalitarianism & & $.62 * *$ & & $.54 * *$ \\
\hline Vested interest & & & $.78 * *$ & $.90 * *$ \\
\hline Ideology & & & .05 & .06 \\
\hline Party registration & & & $.11^{* *}$ & $-.13^{* *}$ \\
\hline Education & $-.10 * *$ & $-.04+$ & .06 & \\
\hline Age & $1.26 * *$ & -.03 & .03 & \\
\hline Age $^{2}$ & $-1.20 * *$ & -.05 & & \\
\hline Income & $-.15 * *$ & $-.16^{* *}$ & $.13+$ & \\
\hline African-American & .05 & $-.14^{* *}$ & $.17^{* *}$ & \\
\hline Woman & .05 & -.05 & .06 & \\
\hline Intercept & -.45 & $2.02 * *$ & -.50 & $-1.84 * *$ \\
\hline
\end{tabular}

because these people qualify for Medicare. Education and income (both at $\mathrm{p}<.01$ ) predict less worry over health care expenses.

The aforementioned heightened worry, in turn, predicts higher values of vested interest $(\mathrm{p}<.05)$, as does egalitarianism $(\mathrm{p}<.01)^{7}$ African-Americans perceive vested interest at lower levels $(\mathrm{p}<.01)$, with income $(\mathrm{p}<.01)$ and education $(\mathrm{p}<.10)$ also predicting lower levels of vested interest. The vested interest, in turn, predicts higher levels of egalitarianism $(p<.01)$. Party registration $(\mathrm{p}<.01)$, income $(\mathrm{p}<.10)$ and African-American $(\mathrm{p}<.01)$ do as well.

We tested for the presence of a causal feedback path from egalitarianism to vested interest, and we do find a statistically significant feedback path $(p<.01){ }^{8}$ However, we note that the standardized coefficients allow us to compare the magnitudes of the effects, and that vested interest has a bit of a larger effect on egalitarianism that egalitarianism has on vested interest. ${ }^{9}$

Finally, we find five direct effects on support for a national health insurance plan. The standardized effects allow us to compare the magnitudes of the effects. The largest effect is for vested interest $(\mathrm{B}=.90, \mathrm{p}<.01)$. The next largest is for egalitarianism $(\mathrm{B}=.54, \mathrm{p}<.01)$. The third largest is for 
worry $(\mathrm{B}=-.31, \mathrm{p}<.05)$. The next largest effect is for party registration $(\mathrm{B}=-.13, \mathrm{p}<.01)$, and the smallest statistically significant effect is for not having health insurance $(\mathrm{B}=.09, \mathrm{p}<.05) .{ }^{10}$ We note two surprising results here: worry decreases support for a national health plan, as does party registration (with Democrats coded as the high value). This suggests that once spurious and intervening factors are controlled for, these factors actually have negative effects. We note, however, that in the case of worry, the total effects are quite small in both the vested interest models.

Importantly, while the antecedent of self-interest has a small direct effect upon the policy preference, the psychological manifestation of that belief in the form of vested interest has a direct and powerful effect. Indeed, the standardized effect coefficient allows one to compare the magnitude of the effect to others, and it is one of the largest in the model. A one-unit increase in vested interest leads to a .90 standard deviation increase in support for a national health insurance program.

In Table 2 we report the results for Model 2, which includes vested interest with the active government political value.

\section{Table 2. The Vested Interest Model of Policy Support with Active Government}

\begin{tabular}{|c|c|c|c|c|}
\hline Variables & Worry & $\begin{array}{l}\text { Vested } \\
\text { Interest }\end{array}$ & $\begin{array}{c}\text { Active } \\
\text { Government }\end{array}$ & $\begin{array}{c}\text { National } \\
\text { Health Plan }\end{array}$ \\
\hline No health coverage & $.10 * *$ & .01 & & $.10 * *$ \\
\hline Difficult to pay medical bills & $.29 * *$ & & & \\
\hline Delayed a major purchase & $.14^{* *}$ & & & \\
\hline Prospective personal finance & $.14 * *$ & & & \\
\hline Prospective national economy & .05 & & & \\
\hline Worry & & $.27 *$ & & -.12 \\
\hline Active Government & & $.55 * *$ & & $.39 * *$ \\
\hline Vested interest & & & $.61^{* *}$ & $.60 * *$ \\
\hline Ideology & & & $.12 * *$ & .05 \\
\hline Party registration & & & $.07^{*}$ & -.01 \\
\hline Education & $-.10 * *$ & -.04 & .03 & \\
\hline Age & $1.26 * *$ & .05 & $-.13^{* *}$ & \\
\hline $\mathrm{Age}^{2}$ & $-1.20 * *$ & -.03 & & \\
\hline Income & $-.15 * *$ & $-.09 *$ & -.05 & \\
\hline African-American & .05 & $-.08 *$ & $.12 * *$ & \\
\hline Woman & .05 & $-.08 *$ & $.11^{* *}$ & \\
\hline Intercept & -.41 & $1.28 * *$ & $2.81 *$ & -.65 \\
\hline
\end{tabular}


The same pattern of results that we report in Table 1 holds here. The antecedents of self-interest increase people's anxiety regarding their health expenses ( $p<.01$ for all results). Age also increases such anxiety $(\mathrm{p}<.01)$, although age-squared decreases it $(\mathrm{p}<.01)$. People with more education and income are also less worried about such expenses $(\mathrm{p}<.01)$.

The antecedents increase anxiety, which in turn increases peoples' sense that a national health care program is in their self-interest $(p<.05)$. The other factor that increases such a sense of self-interest is the political value of active government $(\mathrm{p}<.01)$. The factors that decrease vested interest are income, and being female or African-American (all at $\mathrm{p}<.05$ ).

Vested interest then goes on to increase valuing active government $(\mathrm{p}<.01)$. As with the value of egalitarianism, we find that there is a causal feedback here between vested interest and the political value. However, as before, the relationship from vested interest to the value is slightly stronger than the reverse. Ideology and party registration also increase valuing active government ( $\mathrm{p}<.01$ and $\mathrm{p}<.05$, respectively), as does being female and African-American (both $\mathrm{p}<.01)$. Older people tend to value it less $(\mathrm{p}<.01)$.

We turn now to the results for the direct effects upon support for a national health care program. We find three statistically significant results. The largest is for vested interest $(\mathrm{B}=.60, \mathrm{p}<.01)$. The next largest is for active government $(\mathrm{B}=.39, \mathrm{p}<.01)$. The final statistically significant effect is for not having health insurance $(\mathrm{B}=.10, \mathrm{p}<.01)$.

We conclude reporting results with Tables 3 and 4: models that drop vested interest. In Table 3 we report the results including egalitarianism, and in Table 4 we report results including active government.

In Table 3 we find that the antecedents of self-interest continue to be predictors of worry $(\mathrm{p}<.01)$. Age predicts higher levels of worry as well $(\mathrm{p}<.01)$. Education leads to less worry, as do age-squared and income (all at $\mathrm{p}<.01$ ).

Ideology and party registration lead to higher levels of egalitarianism, and African-Americans and women endorse higher levels of the political value as well $(\mathrm{p}<.01$ for all, but women $\mathrm{p}<.10)$. People with higher incomes endorse egalitarianism at lower levels $(\mathrm{p}<.01)$.

In this model, we find that various factors directly affect support for national health insurance. Not having health insurance predicts greater support $(\mathrm{B}=.14, \mathrm{p}<.01)$. Egalitarianism is the most powerful predictor of support $(\mathrm{B}=.73, \mathrm{p}<.01)$. Health-related anxiety $(\mathrm{B}=.16, \mathrm{p}<.10)$ and ideology $(\mathrm{B}=.12, \mathrm{p}<.01)$ predict support as well. Party registration predicts opposition $(\mathrm{B}=-.13, \mathrm{p}<.05)$.

In Table 4 we report results for the models including active government but lacking vested interest. The pattern of results is the same as before. The antecedents increase levels of worry, as does age $(\mathrm{p}<.01)$. Education decreases worry, as do age-squared and income $(\mathrm{p}<.01)$. Ideology, party 


\section{Table 3. The Basic Self-Interest Model with Egalitarianism: No Vested Interest}

\begin{tabular}{|c|c|c|c|}
\hline Variables & Worry & Egalitarianism & $\begin{array}{c}\text { National } \\
\text { Health Plan }\end{array}$ \\
\hline No health coverage & $.10 * *$ & .02 & $.14^{* *}$ \\
\hline Difficult to pay medical bills & $.28 * *$ & & \\
\hline Delayed a major purchase & $.14^{* *}$ & & \\
\hline Prospective personal finance & $.16^{* *}$ & & \\
\hline Prospective national economy & .03 & & \\
\hline Worry & & & $.16+$ \\
\hline Egalitarianism & & & $.73^{* *}$ \\
\hline Ideology & & $.10 * *$ & $.12 * *$ \\
\hline Party registration & & $.23^{* *}$ & $-.13^{*}$ \\
\hline Education & $-.10 * *$ & .00 & \\
\hline Age & $1.25^{* *}$ & -.04 & \\
\hline Age $^{2}$ & $-1.20 * *$ & & \\
\hline Income & $-.16^{* *}$ & $-.10 * *$ & \\
\hline African-American & .05 & $.14^{* *}$ & \\
\hline Woman & .05 & $.06+$ & \\
\hline Intercept & -.30 & $3.12 * *$ & -.10 \\
\hline
\end{tabular}

Table 4. The Basic Self-Interest Model with Active Government: No Vested Interest

\begin{tabular}{lccc}
\hline Variables & Worry & $\begin{array}{c}\text { Active } \\
\text { Government }\end{array}$ & $\begin{array}{c}\text { National } \\
\text { Health Plan }\end{array}$ \\
\hline No health coverage & $.10^{* *}$ & .02 & $.12^{* *}$ \\
Difficult to pay medical bills & $.28^{* *}$ & & \\
Delayed a major purchase & $.14^{* *}$ & & \\
Prospective personal finance & $.16^{* *}$ & & $.14+$ \\
Prospective national economy & .03 & & $.61^{* *}$ \\
Worry & & $.19^{* *}$ & .06 \\
Active Government & & $.12^{* *}$ & -.02 \\
Ideology & $-.10^{* *}$ & -.02 & \\
Party registration & $1.25^{* *}$ & $-.14^{* *}$ & \\
Education & $-1.21^{* *}$ & $-.20^{* *}$ & \\
Age & $-.16^{* *}$ & $.12^{* *}$ & \\
Age & .05 & $.11^{* *}$ & \\
Income & .05 & $7.73^{* *}$ & .22 \\
African-American & -.45 & & \\
Woman & & & \\
Intercept & & & \\
$* * \mathrm{p}<.01 ; * \mathrm{p}<.05 ;+\mathrm{p}<.10$ (two-tailed tests). Results are standardized estimates using Three-Stage \\
Least Squares regression. Degrees of freedom $=2214$, System-weighted $\mathrm{R}^{2}=.238$. & \\
\hline
\end{tabular}


registration, African-American and female lead to greater endorsement of active government $(\mathrm{p}<.01)$. Age and income lead to opposition $(\mathrm{p}<.01)$. Finally, active government leads people to support a national health care program $(\mathrm{B}=.61, \mathrm{p}<.01)$, as does health-expense related anxiety $(\mathrm{B}=.14$, $\mathrm{p}<.10)$ and not having health insurance $(\mathrm{B}=.12, \mathrm{p}<.01)$.

A comparison of Tables 1 and 2 with 3 and 4 suggests that including vested interest alters the apparent role of self-interest in guiding people's policy preferences. A simple way to evaluate this is to look at the direct effects. Without vested interest, the largest direct effects on support for a national health insurance program are the political values egalitarianism and active government. However, with vested interest, these values play less of a role and are supplanted by the larger effects of vested interest. We will make this case more clearly by considering how including vested interest affects measures of model fit, as well as considering the direct and indirect effects from our path models to compare the total effect of vested interest to the total effect of the symbolic politics variables.

\section{Reporting Changes in Model Fit}

How important is the concept of vested interest to support for a national health care program? One can compare the measures of model fit from the first two models that include vested interest, to the last two to that do not, to ascertain the cost in model fit of excluding vested interest. The first two models have system R-squared statistics of .265 and .260, for the models with egalitarianism and active government, respectively. The second two models, lacking vested interest, have system R-squared statistics of .228 and .238, again with egalitarianism and active government, respectively. In other words, for the models with egalitarianism, dropping vested interest decreases the percent of the variance explained by the independent variables by 3.7 percent, and for the models with active government, the drop is 2.2 percent. These differences are statistically significant at the $\mathrm{p}<.01$ level, using an F-test.

Taking this type of analysis one step further, a common approach in the symbolic politics literature is to compare measures of model fit for models that include only the symbolic politics measures to those that contain only the measures of self-interest (e.g., Lau and Heldman 2009). Typically, the symbolic politics variables explain substantially more of the variance in policy support than the self-interest variables do. We conduct our own statistical exercise of this type to see if including vested interest might produce a different outcome.

We estimate a 3SLS model without any measures of self-interest, but including all of the other variables, as well as the measures of symbolic 
politics (results not reported). For the models with egalitarianism we find an R-squared of .182, and for active government an R-squared of .218. We then estimate a model with all of our measures of self-interest (vested interest and the antecedents of self-interest), and all of the other variables, but none of the symbolic variables, and find an R-squared of .215. One cannot compute a difference in fit statistic because these models are not nested in one another. However, the self-interest model explains 3.3 percent more of the total variance of the endogenous variables than the egalitarian value model, while the measure of model fit for the self-interest model, compared to the active government model, is practically identical. Including vested interest among predictors of policy preference, then, produces models that fit as well as, if not better than, models employing only symbolic variables.

\section{Considering Direct Effects and Indirect Effects}

We presented some preliminary evidence that including vested interest as a measure of self-interest alters one's conclusion about the importance of the role of self-interest. With a path model such as ours, however, one cannot truly assess the total magnitudes of the effects of the independent variables without partitioning the effects into direct and indirect. We engage in this exercise now to demonstrate the importance of vested interest to making self-interest a concept that can compete viably with the variables of symbolic politics.

To begin the comparison of the effects of vested interest versus the antecedents of self-interest, we analyze the results for Tables 3 and 4, in which vested interest is not included, to decompose the direct and indirect effects. We consider this to represent the standard treatment of self-interest, and we engage in this exercise to show how excluding vested interest does reproduce the standard middling effects of self-interest one finds in the literature. We decompose the total effects into direct and indirect effects in Table 5.

We start with the model from Tables 3 and 4, with egalitarianism and active government. The largest total effects are for the political values egalitarianism $(\mathrm{B}=.73)$ and active government $(\mathrm{B}=.61)$. We sum up all of the total effects of the antecedents of self-interest, and all of the total effects of the symbolic politics variables. Consistent with previous findings, the size of the effect of all of the symbolic politics variables is three times larger than the self-interest effects when egalitarianism is in the model, and four times larger when active government is in the model. One would conclude that while self-interest seems to matter, its effect is clearly dwarfed by the variables of symbolic politics. 


\section{Table 5. Direct and Indirect Effects on Support for a National Health Care Program}

\begin{tabular}{|c|c|c|c|c|c|c|}
\hline & \multicolumn{3}{|c|}{$\begin{array}{l}\text { Table } 3 \\
\text { (Basic self-interest model } \\
\text { with egalitarianism as a } \\
\text { political value) }\end{array}$} & \multicolumn{3}{|c|}{$\begin{array}{l}\text { Table } 4 \\
\text { (Basic self-interest model } \\
\text { with active government } \\
\text { as a political value) }\end{array}$} \\
\hline & Direct & Indirect* & Total & Direct & Indirect* & Total \\
\hline No health coverage & .14 & .02 & .16 & .12 & .01 & .13 \\
\hline Difficult medical bills & N/A & .04 & .04 & N/A & .04 & .04 \\
\hline Delaying a major purchase & N/A & .02 & .02 & N/A & .02 & .02 \\
\hline Prospective personal finance & N/A & .03 & .03 & N/A & .02 & .02 \\
\hline \multicolumn{7}{|l|}{ Sum of self-interest } \\
\hline antecedents & .14 & .11 & .25 & .12 & .09 & .21 \\
\hline Political value & .73 & N/A & .73 & .61 & N/A & .61 \\
\hline Ideology & .12 & .07 & .12 & N.S. & .12 & .12 \\
\hline Party registration & -.13 & -.03 & -.16 & N.S. & .07 & .07 \\
\hline Sum of symbolic variables & .72 & .04 & .76 & .62 & .19 & .81 \\
\hline Worry & .25 & N/A & .25 & .14 & N/A & .14 \\
\hline
\end{tabular}

However, bringing vested interest into the equations alters this conclusion. We decompose the total effects for all of the theoretically-important variables from Tables 1 and 2 in Table 6.

The variable with the largest total effect from both tables is vested interest $(\mathrm{B}=1.10$ with egalitarianism and $\mathrm{B}=.68$ with active government). Adding together all of the direct effects of the self-interest variables, and comparing that to the total effect of all of the symbolic politics variables reveals the total effect of self-interest to be larger. Comparing the total effects, one concludes that while the self-interest variables appear to be a bit more important, both sets of variables are roughly equal in magnitude.

\section{Discussion}

\section{Reviewing Hypotheses}

We begin discussing these results by reviewing how well the hypotheses fared in light of the statistical tests. The first hypothesis is that the antecedents of self-interest increase health expense-related anxiety, and the 


\section{Table 6. Direct and Indirect Effects on Support for a National Health Care Program}

\begin{tabular}{|c|c|c|c|c|c|c|}
\hline & \multicolumn{3}{|c|}{$\begin{array}{l}\text { Table } 1 \\
\text { (With egalitarianism } \\
\text { as a political value } \\
\text { and vested interest) }\end{array}$} & \multicolumn{3}{|c|}{$\begin{array}{l}\text { Table } 2 \\
\text { (With active government } \\
\text { as a political value and } \\
\text { vested interest) }\end{array}$} \\
\hline & Direct & Indirect* & Total & Direct & Indirect* & Total \\
\hline No health coverage & .10 & -.01 & .09 & .10 & .01 & .11 \\
\hline Difficult medical bills & N/A & -.04 & -.04 & N/A & .02 & .02 \\
\hline Delaying a major purchase & N/A & -.01 & -.01 & N/A & .00 & .00 \\
\hline Prospective personal finance & N/A & -.02 & -.02 & N/A & .00 & .00 \\
\hline Sum of antecedents & .10 & -.08 & .02 & .10 & .03 & .13 \\
\hline Vested interest & .90 & .20 & 1.10 & .60 & .08 & .68 \\
\hline Sum of self-interest & 1.00 & .12 & 1.12 & .70 & .11 & .81 \\
\hline Political value & .54 & .53 & 1.07 & .39 & .24 & .63 \\
\hline Ideology & N.S. & N.S. & N.S. & N.S. & .07 & .07 \\
\hline Party registration & -.13 & .09 & -.04 & N.S. & .04 & .04 \\
\hline Sum of symbolic variables & .41 & .62 & 1.03 & .39 & .35 & .74 \\
\hline Worry & -.31 & .22 & -.09 & -.12 & .18 & .06 \\
\hline
\end{tabular}

evidence strongly supports this hypothesis. In all four of the models, every antecedent of self-interest increases anxiety at the $\mathrm{p}<.01$ level. The second hypothesis is that this health expense anxiety increases vested interest, and this hypothesis is strongly supported as well -in both models with vested interest, worry increases vested interest at the $\mathrm{p}<.01$ level. The third hypothesis is that vested interest increases support for the political values of egalitarianism and active government. Our results support this hypothesis. However, we also find a strong reciprocal relationship, with egalitarianism and active government affecting vested interest as well. Our fourth hypothesis is that the political values increase support for a national health insurance program. We find that this is the case, with both active government and egalitarianism increasing support for a national health program at the $\mathrm{p}<.01$ level. Finally, we hypothesize that vested interest increases support for a national health insurance program. This hypothesis is strongly supported, as vested interest increases support for the program in each of the two models, and the effects are among the largest in the models. 


\section{Reconsidering a Role for Self-Interest}

Our models confirm our hypotheses, and the strongest confirmation comes for the role of self-interest in affecting people's support for a national health care program. As we noted earlier, the models without vested interest suggest an important but not dominant role for self-interest in shaping these policy preferences. However, once we include vested interest in the model, the total effects of self-interest are among the largest in the model, and they are larger than the total effects of the symbolic politics variables. In addition, the models with the vested interest enjoy better fits with the data than the models without. When including vested interest, the self-interest models fit the data better than, or as well as, the symbolic politics-only models.

These results demand that scholars not close the book on the role of self-interest. Past findings that the role of self-interest is limited are based on studies in which self-interest is not allowed to operate as a psychological concept that varies among individuals. Instead, people who are in certain categories or situations are assumed, by scholars, to be self-interested. This approach does have certain advantages, as researchers have noted (e.g., Sears and Funk 1991). The antecedents of self interest are clearly exogenous from the factors that they are believed to affect. Because of this clear exogeneity, there is no presence of causal feedback from other attitudinal variables of interest. Escalating health expenses are not caused by ideology, or party, or other symbolic political attitudes.

We, of course, define and operationalize self-interest in a different way, finding a powerful role for it. Our definition leads to measures of it that are not exogenous from other symbolic political attitudes. The resulting disadvantage to this approach is that vested interest is associated with ideological identification and some political values, and possibly other symbolic political attitudes. ${ }^{11}$ The advantage of this approach, however, is that it is the superior theoretical way to approach self-interest. First, the theoretical assumption that being in a certain group or condition automatically leads to a self-interested attitude is faulty. Such beliefs should be shaped by individuals' own beliefs and perceptions. Second, theory can account for what these beliefs should be. Third, once we measure vested interest and model it in such a way to account for the beliefs that influence how people perceive their own self-interest, the role of vested interest is powerful. The models with vested interest fit better than those without it, and the size of the effect is large.

A second finding of this study, and a second provocative one at that, is that political values are affected by self-interest. Some scholars of selfinterest argue that such a relationship is impossible (Sears and Funk 1991). However, we find that the values of active government and egalitarianism 
are affected by vested interest. Of course, we do find there is also a projection effect, whereby people find the policy to be in their self-interest because it is consistent with their political values.

Finally, we take note of the role of affect in this model. Affect is the catalyst that brings forth vested interest. Anxiety is probably the most suited emotion to do so, because it brings forth extra thought, which is necessary for people to abandon their predispositions (such as altering their endorsement of political values). The total effect of anxiety in the vested interest models is quite small: weakly negative with egalitarianism $(\mathrm{B}=-.09)$, and weakly positive with active government $(\mathrm{B}=.06)$.

\section{Conclusion}

We conclude by noting some limits to this study. First, the data we employ is from a random sample telephone survey of residents of North Carolina, and thus we cannot generalize our results to the entire U.S. population. That said, theory tells us that we have no reason to believe that the relationships between the antecedents of self-interest, anxiety, vested interest, values, and the policy preference should be any different nationally.

A second caveat has to do with our effect estimates for vested interest. We find large effects for self-interest, but, as we noted, vested interest is not exogenous from symbolic attitudes. It might be the case that some of the magnitude of the relationship is due to other factors not included in the model, such as some other excluded political value. That said, however, we have certainly included the most important factors-active government, egalitarianism, party registration, ideological identification, and anxiety. In addition, we model the causal feedback between vested interest and the political values, thus accounting for them statistically. We contend that while there may be other unaccounted for factors, their impacts on the results should be minimal.

A third caveat has to do with our statistical analysis of cross-sectional survey data. Because we do not have data over time, we have to use an instrumental variables approach to estimate the non-recursive paths. As we reported earlier, tests of the instruments reveal that they are properly identified and exogenous. However, the magnitudes of the paths are partly functions of the exclusion restrictions that are necessary to identify the model given the non-recursive paths. While the tests indicate these are good assumptions, using other instruments, or making other exclusion restrictions, may result in the model reporting different results.

A fourth caveat is that our study involves only one policy preference. While the evidence we present for self-interest influencing support for a national health care program is strong, it may be possible that this model 
cannot be applied universally to all policy preferences. One possible limit on the generalizability of the model could have to do with the kind of affect evoked by the policy. While anxiety has clear links with increased information processing and the willingness to abandon predispositions, other feelings, such as anger and happiness, do not (Marcus et al. 2000). This model may only be applicable when the policy evokes anxiety, because the anxiety may be necessary to increasing vested interest, or for vested interest to affect a political value.

Our fifth and final caveat is that in this model we test only one dimension of the two-dimensional model from Affective Intelligence theory (Marcus et al. 2000). ${ }^{12}$ We consider the impact of the surveillance dimension on processing, and the policy preference, but not the impact of the disposition dimension (which is tapped by happiness). We expect that enthusiasm or happiness leads to more heuristic processing, and thus this feeling would not mediate between the antecedents of self-interest and the policy preference. However, this hypothesis is untestable with our data. In addition, we do not consider the role of anger, and any possible relationship between anger and anxiety.

In conclusion, and with these caveats noted, we believe that our findings present a challenge to the clear consensus in the literature on the minor role of self-interest. We find that when conceived of as vested interest, selfinterest plays a powerful role in shaping policy preferences. We find this when we consider the direct effect of vested interest, as well as the total effect. We also find that self-interest leads people to align their political values to be consistent with perceived self interest, thus increasing support for the relevant policy. Dropping vested interest from these models of policy support reduces how well the models fit the data. Finally, comparing the model fit of the self-interest models to the symbolic politics models reveals that the self-interest models fit the data at least as well as, if not better than, the symbolic politics-only models. 


\section{Appendix A. Demographic Composition of Sample Characteristics of North Carolina Survey Respondents}

\begin{tabular}{|c|c|c|c|c|}
\hline & & $\begin{array}{l}\text { Weighted } \\
\text { Data }\end{array}$ & $\begin{array}{l}\text { Unweighted } \\
\text { Data }\end{array}$ & $\begin{array}{c}\text { Unweighted } \\
\text { N }\end{array}$ \\
\hline \multirow[t]{2}{*}{ Gender } & Male & $48 \%$ & $39 \%$ & 293 \\
\hline & Female & $52 \%$ & $61 \%$ & 455 \\
\hline \multirow[t]{6}{*}{ Race } & White & $73 \%$ & $80 \%$ & 597 \\
\hline & Black & $20 \%$ & $14 \%$ & 103 \\
\hline & Hispanic & $4 \%$ & $2 \%$ & 14 \\
\hline & Asian & $1 \%$ & $1 \%$ & 5 \\
\hline & Native American & $1 \%$ & $2 \%$ & 12 \\
\hline & Other & $1 \%$ & $2 \%$ & 15 \\
\hline \multirow[t]{6}{*}{ Age } & $18-24$ & $13 \%$ & $5 \%$ & 34 \\
\hline & $25-34$ & $20 \%$ & $16 \%$ & 118 \\
\hline & $35-44$ & $22 \%$ & $19 \%$ & 139 \\
\hline & $45-54$ & $18 \%$ & $23 \%$ & 170 \\
\hline & $55-64$ & $12 \%$ & $20 \%$ & 150 \\
\hline & 65 and up & $16 \%$ & $18 \%$ & 137 \\
\hline \multirow[t]{3}{*}{ Education } & High school or less & $24 \%$ & $20 \%$ & 153 \\
\hline & Some college & $37 \%$ & $38 \%$ & 284 \\
\hline & College graduate & $39 \%$ & $42 \%$ & 311 \\
\hline Household & Less than $\$ 10,000$ & $6 \%$ & $4 \%$ & 33 \\
\hline \multirow[t]{5}{*}{ Income } & $\$ 10,000$ to under $\$ 25,000$ & $14 \%$ & $13 \%$ & 98 \\
\hline & $\$ 25,000$ to under $\$ 50,000$ & $27 \%$ & $25 \%$ & 187 \\
\hline & $\$ 50,000$ to under $\$ 75,000$ & $27 \%$ & $28 \%$ & 209 \\
\hline & $\$ 75,000$ to under $\$ 100,000$ & $13 \%$ & $15 \%$ & 111 \\
\hline & $\$ 100,000$ or more & $14 \%$ & $15 \%$ & 110 \\
\hline Total N & & & & 748 \\
\hline
\end{tabular}

\section{Appendix B. Measures}

The data used in this research come from a random-digit-dial statewide telephone survey in North Carolina conducted April 18-26, 2005. The sample consists of interviews with 748 adults ages 18 and older. The survey contained the following measures:

Political value of active government: An additive scale (alpha $=0.72$ ) combining the following questions.

1. Next, I am going to read two statements. Please tell me which statement is closer to your view: The less government, the better; or, there are more things the government should be doing.

2. Please tell me which statement is closer to your view: The government should try to ensure that all Americans have such things as jobs, health care, and housing; or, the government should not be involved in this. 


\section{Appendix B (continued)}

3. Please tell me which statement is closer to your view: We need a strong government to handle today's economic problems; or, the free market can handle these problems without the government getting involved.

(Each of the three active government questions was re-coded so that respondents choosing the less active government statement were coded as 1, those saying they didn't know were coded as 2 , and those choosing the more active government statement were coded as 3 . Combining the three variables created a seven-point scale.)

Antecedents of self interest (four measures):

1. "Are you currently covered by any type of health insurance plan, including private plans, Medicaid, or Medicare?” $(0=$ yes and $1=$ no)

2. "For various reasons, some people have difficulty paying their medical bills, while others are able to pay those expenses. In the past six months, have you had to take extra steps, such as borrowing money or using money from a savings account, to help pay medical bills?" $(0=$ no and $1=$ yes $)$

3. In the past six months, have you had to do any of the following? Delay buying a large item, such as a major appliance or car. $(0=$ no/don't know/no response, $1=$ yes $)$

4. Do you expect your personal financial position to get better, get worse or stay about the same within the next year? $(1=$ get better, 2 = stay about the same, $3=$ get worse $)$

Prospective national economic outlook:

Do you expect our national economy to get better, get worse, or stay about the same within the next year? ( 1 = get better, 2 = stay about the same, 3 = get worse)

Affect: "Are you concerned about being able to pay medical bills for you and your family? Which statement best describes your feelings about paying medical bills?" There were four response categories, ranging from, "I am not worried" to "I am very worried." We recoded "don't know" responses to place them at the midpoint of a five-point scale.

Ideology: We measured political ideology using a seven-point scale ranging from $1=$ extremely conservative to 7 = extremely liberal.

Partisanship: Measure of political party registration, with $-1=$ Republican, $1=$ Democrat, $0=$ all others.

Age: 2005-year of birth.

Age squared: Squared term to measure curvilinear effects of age.

Education: Highest level of education with $1=$ some high school (or less), $2=$ high school graduate, 3 = some college, but no college degree, 4 = associate degree, 5 = bachelor's degree, $6=$ some graduate school, but no graduate degree, $7=$ graduate school degree (includes master's, Ph.D., law or medical).

Income: Annual household income, with $1=$ Less than $\$ 10,000,2=\$ 10,000$ to under $\$ 25,000,3=\$ 25,000$ to under $\$ 50,000,4=\$ 50,000$ to under $\$ 75,000,5=\$ 75,000$ to under $\$ 100,000,6=\$ 100,000$ or more. 


\section{Appendix C. Assessing the Three Stage Least Square Model's Assumptions Three Stage Least Squares: Vested Interest Model of Policy Support}

\begin{tabular}{|c|c|c|c|}
\hline $\begin{array}{l}\text { Vested Interest } \\
\text { (Egalitarianism) }\end{array}$ & $\begin{array}{l}\text { Egalitar- } \\
\text { ianism }\end{array}$ & $\begin{array}{l}\text { Vested Interest } \\
\text { (Active } \\
\text { Government) }\end{array}$ & $\begin{array}{l}\text { Active } \\
\text { Govern- } \\
\text { ment }\end{array}$ \\
\hline
\end{tabular}

[A] Under-identification Test: Anderson Canon. Corr.

LM statistic (p-value)

$54.4(\mathrm{p}<.01) \quad 71.2(\mathrm{p}<.01) \quad 78.8(\mathrm{p}<.01) 71.2(\mathrm{p}<.01)$

[B] Weak identification test:

Cragg-Donald Wald

F Statistic

[C] Over-identification test of all instruments:

Sargan Chi-Square

Statistic (p-value)

$2.1(\mathrm{p}=.15)$

$0(\mathrm{p}=.99)$

$.001(\mathrm{p}=.98) \quad .76(\mathrm{p}=.38)$

Analysis of results:

[A] The under-identification test tests the relevance of the instruments to the endogenous variable. If the null hypothesis is rejected, then the equation is identified and the instruments (the variables that affect the endogenous variable only) are relevant. In these models we reject the null hypothesis, $\mathrm{p}<.01$.

[B] With the weak identification test we test whether or not the instruments are weak instruments; in others words, that they are only weakly correlated with the endogenous variables. Instruments are considered to be weak if the resulting F statistic is less than 10 (Staiger and Stock 1997). All of the statistics here are greater than 10.

[C] The over-identification test checks whether or not the instruments are correlated with the equations' error terms. If they are correlated, the parameters are biased. The null hypothesis is that they are not correlated, and that the exclusion restrictions are correct. We accept the null hypothesis for all equations, $\mathrm{p}>.10$.

\section{NOTES}

${ }^{1}$ In the vote choice literature specifically, the originally minimal role found for pocketbook voting is giving way to a more nuanced understanding of when voters do, and do not, use their own personal economic conditions to make their vote choices. Originally, scholars concluded that voters voted based on sociotropic, and not pocketbook, economic reasoning (e.g., Kinder and Kiewiet 1979; Kiewiet 1983; Sigelman et al. 1991). Some scholars found that both mattered, although sociotopic factors mattered more (Markus 1988). However, more recent scholarship finds a role for pocketbook voting (in Congressional elections or evaluations, Romero and Stambough 1996; Rudolph 2002; or, in Presidential elections, Grafstein 2005; Gomez and Wilson 2001).

${ }^{2}$ Recent work suggests a reason for these results is because people use their notions of self-interest to make decisions about things that will affect them immediately, while using symbolic considerations to make decisions about issues that occur more distantly in the future (Hunt et al. 2010). 
${ }^{3}$ This concept of vested interest requires that scholars measure individuals' perceptions of their own self-interest. Such measures are absent from most data. Even when measures of vested interest are missing, however, the antecedents of self-interest clearly moderate the effect of symbolic attitudes. As a debate in the literature between William Crano and David Sears reveals, as well as later work by Lehman and Crano, symbolic attitudes have more effects on policy preferences among those whose self-interest is high (for the debate, see Crano 1997a, 1997b, and Sears 1997; see also Lehman and Crano 2002).

${ }^{4}$ For a neurochemical explanation, see Jeffrey Alan Gray (1987).

${ }^{5}$ This suggests that the directions of the causal relationships may not be entirely clear-cut. Indeed, such complications are a major reason that the antecedents approach to self-interest dominates the literature, because the alternative we propose is messy. However, we contend that it is the empirically more accurate way to see self-interest.

${ }^{6}$ For evidence of this in the political realm, see Barnea and Schwartz (1998), Caprara et al. (2006), Feldman (1988), Feldman and Steenbergen (2001), and Goren (2005).

${ }^{7}$ There were only two "don't know" responses to the measure of affect. At the suggestion of an anonymous reviewer, we re-ran the analyses omitting the "don't know" responses from the measure of affect, and also coding "don't know" along with "I am not worried" as the lowest value in the variable. Both approaches yielded results virtually identical to the results that we report here. Also at the suggestion of an anonymous reviewer, we ran analyses using a squared measure of affect to test for a curvilinear effect. Results using the squared term did not differ significantly from what we report here.

${ }^{8}$ This feedback is consistent with MacCoun and Paletz (2009), who find that ideologues discount research findings when they conflict with their own ideological beliefs. In our view, this is similar to people discounting public policies that would benefit them, when the policies conflict with their political values-based beliefs.

${ }^{9}$ We include one antecedent of self-interest as a predictor of vested interest: not having health insurance. We include this variable because it is a strong instrument for vested interest (see Appendix B).

${ }^{10}$ Lacking health coverage is the only antecedent of self-interest that we model as directly affecting support for a national health insurance plan. We exclude the others to help identify the model. However, in other versions of the model, we find the direct effects of the other antecedents to be small and typically statistically insignificant (results not reported).

${ }^{11}$ Thus, we control for party identification, ideological identification, egalitarianism and active government in our models.

${ }^{12}$ We thank an anonymous reviewer for bringing this to our attention.

\section{REFERENCES}

Baron, Jonathan, and Sarah Leshner. 2000. How Serious are Expressions of Protected Values? Journal of Experimental Psychology: Applied 6(3):183-194.

Barnea, Marina F., and Shalom H. Schwartz. 1998. Values and Voting. Political Psychology 19(March):17-40.

Bernard, Mark M., Gregory R. Maio, and James M. Olson. 2003. The Vulnerability of Values to Attack: Inoculation of Values and Value-Relevant Attitudes. Personality and Social Psychology Bulletin 29(1):63-75. 
Berry, William D. 1984. Nonrecursive Causal Models. Thousand Oaks, CA: Sage Publications.

Boninger, David S., Jon A. Krosnick, and Matthew K. Berent. 1995. Origins of Attitude Importance: Self-Interest, Social Identification and Value Relevance. Journal of Personality and Social Psychology 68(1):61-80.

Calhoun-Brown, Allison. 1996. African-American Churches and Political Mobilization: The Psychological Impact of Organizational Resources. Journal of Politics 58(4): 935-953.

Caprara, Gian Vittoro, Shalom Schwartz, Cristina Capanna, Michele Vecchiore, and Claudio Barbaranelli. 2006. Personality and Politics: Values, Traits and Political Choice. Political Psychology 27(February):1-28.

Crano, William D. 1995. Attitude Strength and Vested Interest. In Attitude Strength: Antecedents and Consequences, eds. Richard E. Petty and Jon A. Krosnick. Mahwah, NJ: Lawrence Earlbaum Associates.

Crano, William D. 1997a. Vested Interest, Symbolic Politics, and Attitude-Behavior Consistency. Journal of Personality and Social Psychology 72(3):485-491.

Crano, William D. 1997b. Vested Interest and Symbolic Politics-Observations and Recommendations: Reply to Sears (1997). Journal of Personality and Social Psychology 72(3):497-500.

Eagly, Alice H., and Shelly Chaiken. 1998. Attitude Structure and Function. Pp. 269-322 in Handbook of Social Psychology. Columbus, OH: McGraw-Hill.

Feldman, Stanley. 1987. Evaluation of New Equality Items. Technical Report to the American National Election Study, September 29.

Feldman, Stanley. 1988. Structure and Consistency in Public Opinion: The Role of Core Beliefs and Values. American Journal of Political Science 32:416-440.

Feldman, Stanley, and Marco Steenbergen. 2001. The Humanitarian Foundation of Public Support for Social Welfare. American Journal of Political Science 45(July):658677.

Feldman, Stanley, and Leonie Huddy. 2005. The Paradoxical Effects of Anxiety on Political Learning. Paper presented at the Annual Meeting of the Midwest Political Science Association, Chicago, April.

Godwin, Deborah D. 1985. Simultaneous Equations in Family Research. Journal of Marriage and the Family 47(February):9-22.

Gomez, Brad T., and J. Matthew Wilson. 2001. Political Sophistication and Economic Voting in the American Electorate: A Theory of Heterogeneous Attribution. American Journal of Political Science 45(October):899-914.

Goren, Paul. 2005. Party Identification and Core Political Values. American Journal of Political Science 49:881-896.

Grafstein, Robert. 2005. The Impact of Employment Status on Voting Behavior. Journal of Politics 67(August):804-824.

Gray, Jeffrey A. 1987. The Psychology of Fear and Stress. Cambridge: Cambridge University Press.

Hamilton, Alexander, James Madison, and John Jay. 1961. The Federalist Papers. New York: Signet Classics.

Holahan, John, and Allison Cook. 2005 (Nov. 1). Changes in Economic Conditions and Health Insurance Coverage, 2000-2004. Health Affairs. Retrieved January 3, 2006 from http://content.healthaffairs.org/cgi/reprint/hlthaff.w5.498v1?ijkey= QG3WTSW8ppHpE\&keytype=ref\&siteid=healthaff.

Huddy, Leonie, Stanley Feldman, and Erin Cassese. 2007. On the Distinct Political Effects of Anxiety and Anger. Pp. 202-230 in The Affect Effect: Dynamics of 
Emotion in Political Thinking and Behavior, eds. W. Russell Neuman, George E. Marcus, Ann Crigler, and Michael MacKuen. Chicago: University of Chicago Press.

Hunt, Corrie V., Anita Kim, Eugene Borgida, and Shelly Chaiken. 2010. Revisting the Self-Interest versus Values Debate: The Role of Temporal Perspective. Journal of Experimental Social Psychology 46:1155-1158.

Kiewiet, D. Roderick. 1983. Macroeconomics and Micropolitics. Chicago: University of Chicago Press.

Kinder, Donald R., and D. Roderick Kiewiet. 1979. Economic Discontent and Political Behavior: The Role of Personal Grievances and Collective Economic Judgments in Congressional Voting. American Journal of Political Science 23(August):495-527.

Lau, Richard R., and Caroline Heldman. 2009. Self-Interest, Symbolic Attitudes, and Support for Public Policy: A Multi-Level Analysis. Political Psychology 30(August):513-537.

LeDoux, Joseph. 1996. The Emotional Brain: The Mysterious Underpinnings of Emotional Life. New York: Simon and Schuster.

Lehman, Barbara J., and William D. Crano. 2002. The Pervasive Effects of Vested Interest on Attitude-Criterion Consistency in Political Judgment. Journal of Experimental Social Psychology 38:101-112.

MacCoun, Robert J., and Susannah Paletz. 2009. Citizens Perceptions of the Ideological Bias in Research on Public Policy Controversies. Political Psychology 30(February):43-66.

Maio, Gregory R., and James M. Olson. 1998. Values as Truisms: Evidence and Implications. Journal of Personality and Social Psychology 74(2):294-311.

MacKuen, Michael, George E. Marcus, W. Russell Neuman, and Luke Keele. 2007. The Third Way: The Theory of Affective Intelligence and American Democracy. Pp. 124-151 in The Affect Effect: Dynamics of Emotion in Political Thinking and Behavior, eds. W. Russell Neuman, George E. Marcus, Ann Crigler, and Michael MacKuen. Chicago: University of Chicago Press.

Marcus, George E., W. Russell Neuman, and Michael B. MacKuen. 2000. Affective Intelligence and Political Judgment. Chicago: University of Chicago Press.

Markus, Gregory B. 1988. The Impact of Personal and National Economic Conditions on the Presidential Vote: A Pooled Cross-Sectional Analysis. American Journal of Political Science 32(February):137-154.

Markus, Gregory. 1990. Measuring Popular Individualism. Technical report to the American National Election Study.

McCann, James A. 1997. Electoral Choices and Core Value Change: The 1992 Presidential Election. American Journal of Political Science 41(2):564-583.

Nadeau, Richard, Richard G. Niemi, and Timothy Amato. 1995. Emotions, Issue Importance, and Political Learning. American Journal of Political Science 39(August): 558-574.

Ortony, Andrew, Gerald C. Clore, and Allan Collins. 1988. The Cognitive Structure of Emotions. Cambridge: Cambridge University Press.

Panskepp, Jaak. 1998. Affective Neuroscience: The Foundations of Human and Animal Emotions. Oxford: Oxford University Press.

Petty, Richard E., and John T. Cacioppo. 1986. Communication and Persuasion: Central and Peripheral Routes to Attitude Change. New York: Springer-Verlag.

Prisline, Radmila, and Judith Ouellette. 1996. When it is Embedded, it is Potent: Effects of General Attitude Embeddedness on Formation of Specific Attitudes and Behavioral Intentions. Personality and Social Psychology Bulletin 22(8):845-861. 
Redlawsk, David P., Andrew J.W. Civettini, and Richard R. Lau. 2007. Affective Intelligence and Voting: Information Processing and Learning in a Campaign. Pp. 152-179 in The Affect Effect: Dynamics of Emotion in Political Thinking and Behavior, eds. W. Russell Neuman, George E. Marcus, Ann Crigler, and Michael MacKuen. Chicago: University of Chicago Press.

Romero, David W., and Stephen J. Stambough. 1996. Personal Economic Well-Being and the Individual Vote for Congress: A Pooled Analysis, 1980-1990. Political Research Quarterly 49(September):607-616.

Rudolph, Thomas J., Amy Gangl, and Dan Stevens. 2000. The Effects of Efficacy and Emotion on Campaign Involvement. Journal of Politics 62(4):1189-1197.

Rudolph, Thomas J. 2002. The Economic Sources of Congressional Approval. Legislative Studies Quarterly 27(November):577-599.

Sears, David O. 1997. The Impact of Self-Interest on Attitudes-A Symbolic Politics Perspective on Differences Between Survey and Experimental Findings: Comment on Crano (1997). Journal of Personality and Social Psychology 72(3):492-496.

Sears, David O., and Carolyn L. Funk. 1991. The Role of Self-Interest in Social and Political Attitudes. Advances in Experimental Social Psychology 24:1-91.

Sears, David O., and Carolyn L. Funk. 1999. Evidence of the Long-Term Persistence of Adults' Political Predispositions. Journal of Politics 61(1):1-28.

Sigelman, Lee, Carol K. Sigelman, and David Bullock. 1991. Reconsidering Pocketbook Voting: An Experimental Approach. Politcal Behavior 13(2):129-149.

Staiger, Douglas, and James H. Stock. 1997. Instrumental Variables Regression with Weak Instruments. Econometrica 65:557-586.

Valentino, Nicholas A., Antoine J. Banks, Vincent L. Hutchings, and Anne K. Davis. 2009. Selective Exposure in the Internet Age: The Interaction Between Anxiety and Information Utility. Political Psychology 30(August):591-614.

Valentino, Nicholas A., Vincent L. Hutchings, Antoine J. Banks, and Anne K. Davis. 2008. Is a Worried Citizen a Good Citizen? Emotions, Political Information Seeking, and Learning via the Internet. Political Psychology 29(April):247-273.

Verplanken, Bas, and Rob W. Hollard. 2002. Motivated Decision Making: Effects of Activation and Self-Centrality of Values on Choices and Behavior. Journal of Personality and Social Psychology 82(3):434-447. 